This item was submitted to Loughborough's Research Repository by the author.

Items in Figshare are protected by copyright, with all rights reserved, unless otherwise indicated.

\title{
The impact of dementia on women internationally: an integrative review
}

\section{PLEASE CITE THE PUBLISHED VERSION}

http://dx.doi.org/10.1080/07399332.2016.1219357

\section{PUBLISHER}

(C) Taylor \& Francis Group, LLC

\section{VERSION}

AM (Accepted Manuscript)

\section{PUBLISHER STATEMENT}

This work is made available according to the conditions of the Creative Commons Attribution-NonCommercialNoDerivatives 4.0 International (CC BY-NC-ND 4.0) licence. Full details of this licence are available at: https://creativecommons.org/licenses/by-nc-nd/4.0/

\section{LICENCE}

CC BY-NC-ND 4.0

\section{REPOSITORY RECORD}

Erol, Rosie, Dawn Brooker, and Elizabeth Peel. 2019. "The Impact of Dementia on Women Internationally: An Integrative Review”. figshare. https://hdl.handle.net/2134/22314. 
(C) Erol, R., Brooker, D. \& Peel, E. (2016) The impact of dementia on women internationally: An integrative review. Health Care for Women International. doi:10.1080/07399332.2016.1219357

*Please cite published version*

\title{
The Impact of Dementia on Women Internationally: An integrative review
}

\begin{abstract}
Women are disproportionately affected by dementia, both in terms of developing dementia and becoming caregivers. We conducted an integrative review of English language literature of the issues affecting women in relation to dementia from an international perspective. The majority of relevant studies were conducted in high income countries, and none were from low-income countries. The effects of caregiving on health, wellbeing and finances are greater for women; issues facing women, particularly in low and middle-income countries need to be better understood. Research should focus on building resilience to help people adjust and cope long term.
\end{abstract}

Dementia is a global public health issue that disproportionately affects women, either through developing the condition themselves, or as a carer for someone with dementia. The effects on women of living with or caring for someone with dementia from an international perspective needs to be more fully understood. In our review of the published literature, we explore the impact of dementia on changing roles, identity, wellbeing and finances for women in both high-income and low- and middle income countries. An improved understanding of these factors can support research, and policy developments, that address the issues specifically relevant to women.

As age is the greatest risk factor for dementia, and women have a greater life expectancy worldwide than men, a larger number of people with dementia are women (Alzheimer's Association, 2014). There are also clinical differences between genders in disease risk and severity, especially in relation to dementia and cognition (Carter et al., 2012). There is a significant association between age, gender, and dementia in many areas of the world, with women showing a higher prevalence rate for dementia than men (Bamford, 2011; Takeda et al., 2011; Alzheimer's Disease 
(C) Erol, R., Brooker, D. \& Peel, E. (2016) The impact of dementia on women internationally: An integrative review. Health Care for Women International. doi:10.1080/07399332.2016.1219357

*Please cite published version*

International, 2015) across both high income countries (HICs) and low and middle income countries (LMICs) (Braun, 2012; Alzheimer's Disease International, 2013). The rate of increase of people with dementia is higher in LMICs. In 2015, 58 per cent of all people with dementia lived in LMICs. This is expected to rise to 68 per cent by 2050 (Alzheimer's Disease International, 2015), disproportionately affecting women due to higher prevalence and incidence, especially as age increases.

Around two-thirds of people with dementia live in the community in their own homes (Alzheimer's Association, 2014; Alzheimer's Society, 2011), with a higher proportion in LMICs (Alzheimer's Disease International, 2009). The responsibility for care for those affected by dementia falls to family carers across most areas of the world (Carter et al., 2012; Alzheimer's Disease International, 2010; Iavarone et al., 2014), of whom two-thirds are reported to be women (Alzheimer's Association, 2014; Prince, 2004). In both developed and developing countries, there is often a social expectation that women will assume caregiving roles (Godfrey \& Warshaw, 2009; Lantz, 2009; Gibbons et al., 2014). In many studies of dementia caregivers, all or most participants are women, reflecting the disproportionate extent to which women are relied upon as carers, although few reports focus on gender specifically (Robinson et al., 2014). Therefore the assumption that women provide informal care to people with dementia is embedded (often implicitly) in much of the existing research.

The financial impact of providing dementia care on family caregivers is substantial; caregivers in the United States reported that they were reluctant to take time off 
(C) Erol, R., Brooker, D. \& Peel, E. (2016) The impact of dementia on women internationally: An integrative review. Health Care for Women International. doi:10.1080/07399332.2016.1219357

*Please cite published version*

work to provide care, or took on additional work to cover caregiving costs, which had increased because of the recent economic downturn (Evercare, 2009). Women may also have the responsibility of caring for young children alongside caring for a parent with dementia -referred to as the 'sandwich generation' (Solberg et al., 2014). Despite this (often dual) caring responsibility, families often prefer, for a variety of cultural, obligational and practical reasons to continue to provide care at home rather than seek alternative care arrangements (AAARP, 2015).

Gender differences are also apparent in terms of prevention and delaying onset of dementia. Diet (Pinder, 2008), physical activity, and body weight seem to have a positive impact on the risk of future dementia and cognitive decline. However, these factors do not appear to slow or reverse dementia once women reach their 70 s (Godfrey \& Warshaw, 2009). Mental activity (such as reading, playing games), attaining higher education (Ochayi \& Thacher, 2006), socialisation and an active lifestyle have the greatest potential for reducing risk of developing dementia. However, women in LMICs are less likely than men to have access to education or spend fewer years in education (Ochayi \& Thacher, 2006).

As the population ages and the prevalence of dementia increases, in both LMICs and HICs, an adequately skilled and sufficiently large dementia care workforce is essential to meet long-term care needs (World Health Organisation and Alzheimer's Disease International, 2012; Coogle et al., 2007; Bruckner et al., 2011; Elliott et al., 2012; Elliott et al., 2013). As with informal caregivers, the majority of formal paid health and social care for people with dementia is provided by women, who make 
(C) Erol, R., Brooker, D. \& Peel, E. (2016) The impact of dementia on women internationally: An integrative review. Health Care for Women International. doi:10.1080/07399332.2016.1219357

*Please cite published version*

up over 85 per cent of this workforce (Alzheimer's Association, 2014; Cummings et al, 2013). Thus there is a growing recognition of the role of gender relating to dementia, with emerging evidence suggesting the need to prioritize dementia as a global women's health issue (Savitch et al., 2015).

The health and financial impact of dementia worldwide underlines dementia as a global public health priority that needs appropriate investment and action by individual countries, to ensure appropriate policies and systems are in place to support people with dementia and their carers, especially women (World Health Organisation and Alzheimer's Disease International, 2012; Alzheimer's Disease International, 2015).

The key aim in conducting this integrative review was to understand the main issues affecting women in relation to dementia from an international perspective. Our objectives were to: 1) explore research relating specifically to women and dementia; 2) examine the effect of gender on women living with dementia and informal female carers and; 3) understand the issues affecting these groups of women with specific reference to LMICs, family structures and kinship, and migration and immigration.

\section{Methods}

\section{Data search and selection}

An integrative review process was followed, to include a broad range of published literature, and allowing the inclusion and integration of research using diverse 
(C) Erol, R., Brooker, D. \& Peel, E. (2016) The impact of dementia on women internationally: An integrative review. Health Care for Women International. doi:10.1080/07399332.2016.1219357

*Please cite published version*

methodologies (Whittemore \& Knafl, 2005). We systematically searched the databases Academic Search Complete, CINAHL, PsychINFO, Medline, Web of Science, PubMed and Google Scholar, alongside a search of relevant government department and third sector organisation websites and a general internet search. Search terms included: dementia, Alzheimer's; women, gender, female, feminis*; caregiv*, family carer, partner, spouse, daughter, mother, migration, immigration, language; and famil*, structure, kinship, culture. Inclusion criteria were: published between January 2005 and December 2014, to provide the most recent research at the time the review was conducted; English language but with worldwide coverage; empirical research, review and expert opinion articles, with searches of titles, keywords, and abstracts. We excluded articles relating solely to medical intervention or clinical treatment, and biomedical research. Unpublished dissertations, policy and news articles were also excluded.

\section{Data extraction and synthesis}

A total of 36 searches of the relevant databases were conducted, from which 1270 papers were screened (from title and abstract) for relevance, giving 170 potentially relevant abstracts. Of these abstracts, the full text of 32 could not be accessed in the time available, 1 was the abstract of an unpublished conference paper and 13 were unpublished dissertations, which resulted in 124 full papers being retrieved for quality review. Further review of the full papers resulted in 63 being excluded due to not being fully relevant or not meeting inclusion criteria. Of those excluded, 28 were excluded as the majority of participants were female, but gender was not discussed at all; 6 were not focused on dementia care; in 24, gender was mentioned 
(C) Erol, R., Brooker, D. \& Peel, E. (2016) The impact of dementia on women internationally: An integrative review. Health Care for Women International. doi:10.1080/07399332.2016.1219357

*Please cite published version*

but was not the focus of the research; 3 did not present any method; 1 was an

editorial and 1 was a news article. This resulted in 61 papers being included in the review, with a particular focus on 22 papers which were concerned specifically with women and dementia.

Figure 1: PRISMA Flow chart for the selection of studies on women and dementia

Records identified through database searching $(n=1264)$
Additional records identified through Google Scholar and internet search $(n=6)$

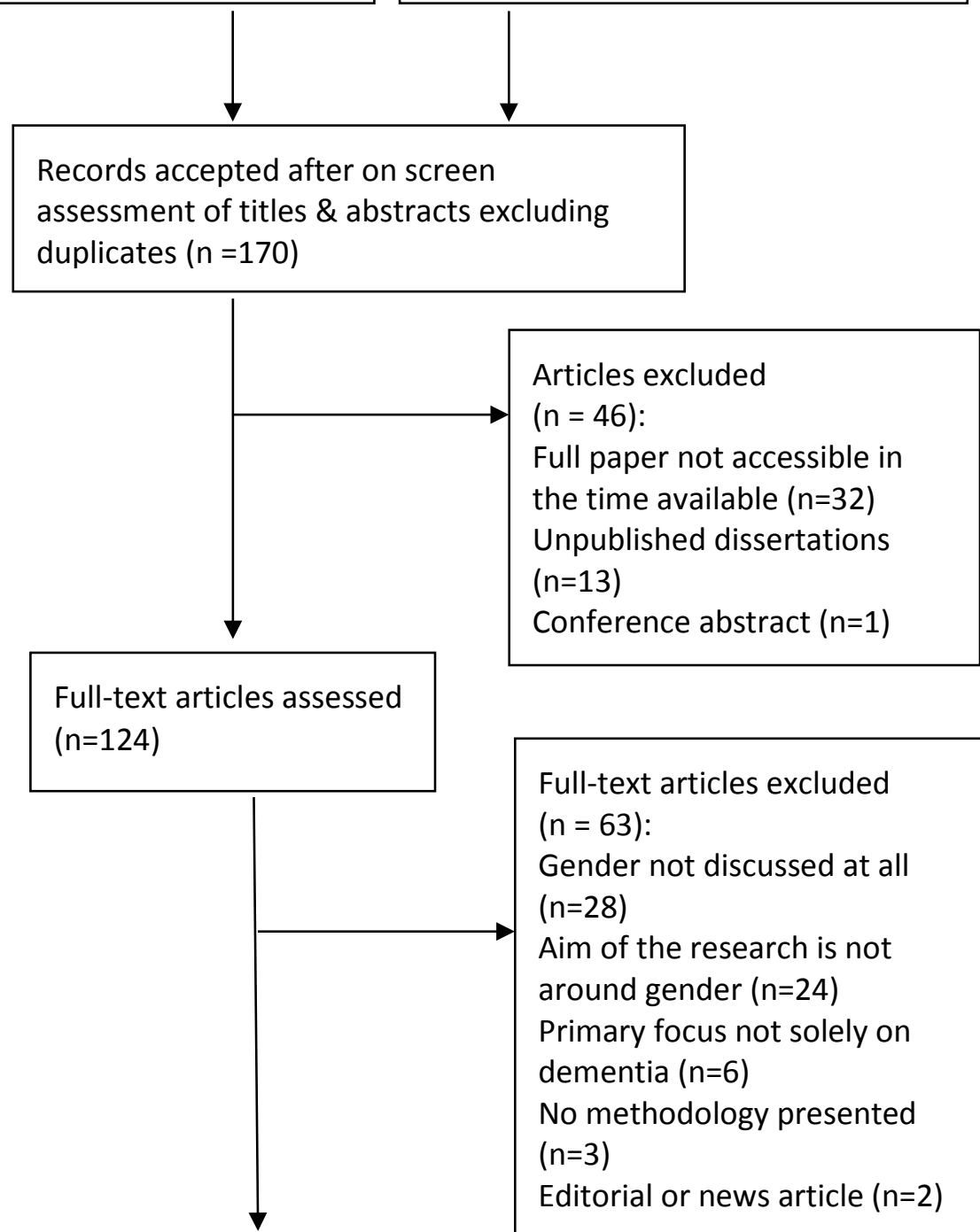

Studies included in full review $(n=61)$ 
(C) Erol, R., Brooker, D. \& Peel, E. (2016) The impact of dementia on women internationally: An integrative review. Health Care for Women International. doi:10.1080/07399332.2016.1219357

*Please cite published version*

We developed a data extraction tool to collate relevant information about aims/objectives, method, findings, conclusions, and limitations adapted from the EPPI-Centre approach to assessing and synthesizing research evidence derived from various methodological approaches (Harden \& Thomas, 2005; Jackson et al., 2005).

\section{Table 1: Country of focus}

\begin{tabular}{|ll|ll|}
\hline $\begin{array}{l}\text { Upper-middle- } \\
\text { income economies }\end{array}$ & High income economies \\
\hline South 1 & USA & 26 \\
Africa & & & \\
Turkey 1 & Canada & 9 \\
& & UK & 8 \\
& Spain & 3 \\
& Japan & 3 \\
& Cyprus & 2 \\
& & Finland & 2 \\
& Sweden & 1 \\
& Israel & 1 \\
& Czech & 1 \\
& Republic & \\
& Germany & 1 \\
& Netherlands & 1 \\
& Norway & 1 \\
\hline & & $\mathbf{5 9}$ \\
\hline
\end{tabular}

An analysis of the country/area of focus for the analyzed studies showed that the majority of the research has been conducted in North America and Europe. There was very little research relating to LMICs, with only two papers emerging from the 
(C) Erol, R., Brooker, D. \& Peel, E. (2016) The impact of dementia on women internationally: An integrative review. Health Care for Women International. doi:10.1080/07399332.2016.1219357

*Please cite published version*

search that considered gender issues in the context of dementia in upper-middle income economies. None of the articles reported research that had been conducted in low income or lower-middle income countries. We also categorized the articles by the participant group the study focused upon (Table 2).

Table 2: Participant group and research focus

\begin{tabular}{lc}
\hline \multicolumn{1}{c}{ Participant group/focus } & Number of papers \\
\hline Caregivers & 46 \\
Person with dementia & 9 \\
Prevalence & 1 \\
Specific population groups/nationalities & 2 \\
Person with dementia and caregivers & 3 \\
Total & $\mathbf{6 1}$ \\
\hline
\end{tabular}

As Table 2 shows, three quarters of the papers focused on women as caregivers as the main participant group. There were far fewer papers focusing on women living with dementia. Both of the papers published from the upper middle-income countries focused on caregiving. The findings of the articles were then synthesized around two main groups, namely women with dementia, and family caregivers.

\section{Results}

\section{Overview of the papers included}

This paper presents a review of 61 papers around women and dementia. For the purposes of the analysis, the papers were split into two groups: those that focused specifically on women and gender (group A), and those that focused on men, or gender more generally (group B) (table 3). The majority of research papers in group A (14 out of 22 studies) used qualitative methods; group B studies were predominantly quantitative in this approach (26 out of 39 papers). This potentially 
(C) Erol, R., Brooker, D. \& Peel, E. (2016) The impact of dementia on women internationally: An integrative review. Health Care for Women International. doi:10.1080/07399332.2016.1219357

*Please cite published version*

reflects the need to use methods that provide an in-depth understanding of the individual experiences affecting women in relation to dementia, rather than as a generalizable, homogenous group. A summary of the group A studies is shown in table 4.

Table 3: Methodological approaches of the reviewed papers, by group

\begin{tabular}{|c|c|c|c|}
\hline Methodology & $\begin{array}{l}\text { Group A: focused } \\
\text { specifically on } \\
\text { women and } \\
\text { gender }\end{array}$ & $\begin{array}{l}\text { Group B: focused } \\
\text { more generally } \\
\text { on gender and } \\
\text { dementia }\end{array}$ & Total \\
\hline Qualitative & 14 & 8 & 22 \\
\hline Quantitative & 4 & 26 & 30 \\
\hline Systematic/literature review & - & 4 & 4 \\
\hline Mixed methods & 1 & 1 & 2 \\
\hline Evidence based expert opinion & 3 & - & 3 \\
\hline Grand Total & 22 & 39 & 61 \\
\hline
\end{tabular}




\section{Table 4: Summary of group A studies reviewed}

\begin{tabular}{|c|c|c|c|c|}
\hline Study & Country & Aims \& objectives & Method & Key Findings relating to Women and Dementia \\
\hline $\begin{array}{l}\text { Alzheimer's } \\
\text { Association (2014) }\end{array}$ & USA & $\begin{array}{l}\text { annual review of Alzheimer's and other } \\
\text { related dementias in the USA, with a } \\
\text { focus on women and dementia }\end{array}$ & $\begin{array}{l}\text { Cross sectional questionnaire on attitudes, } \\
\text { knowledge and experiences related to } \\
\text { dementia. } N=3102 \text { American adults. Analysed } \\
\text { using descriptive statistics. }\end{array}$ & $\begin{array}{l}\text { Women account for } 63 \% \text { of dementia caregivers. The } \\
\text { higher caregiving burden can cause higher emotional } \\
\text { and physical stress, strained family relationships, and } \\
\text { lost employment opportunities }\end{array}$ \\
\hline Borley et al. (2014) & UK & $\begin{array}{l}\text { to explore the lived experience of } \\
\text { becoming cared for from the perspective } \\
\text { of a woman with AD; offers a female } \\
\text { gendered viewpoint to explore } \\
\text { traditional gender roles and a woman's } \\
\text { sense of self and identity. }\end{array}$ & $\begin{array}{l}\text { Qualitative case study of an } 83 \text { year-old } \\
\text { women with mild dementia living with her } \\
\text { husband, from two semi-structured } \\
\text { interviews. }\end{array}$ & $\begin{array}{l}\text { key experiences identified focus on connection to past } \\
\text { self and maintaining that identity. The transition from } \\
\text { caring for role to a cared for role is difficult; linked to } \\
\text { identity as being central to family life. }\end{array}$ \\
\hline Boyle (2013) & UK & $\begin{array}{l}\text { to explore the social processes of } \\
\text { everyday decision making by couples } \\
\text { living with dementia }\end{array}$ & $\begin{array}{l}\text { Cross sectional. Ethnographic approach, with } \\
\text { couples in their homes over } 4+\text { visits; actual } \\
\text { and perceived decision making abilities were } \\
\text { assessed. } \mathrm{N}=42 \text { ( } 21 \text { married couples, } 12 \\
\text { women and } 9 \text { men with dementia) }\end{array}$ & $\begin{array}{l}\text { Wife carers were more likely to use facilitative support } \\
\text { approaches than men; husband carers adopted } \\
\text { supervisory or overseeing roles. Women with } \\
\text { dementia may be excluded from decision making } \\
\text { processes for daily activities; spouses of both sexes } \\
\text { often excluded their partners with dementia from } \\
\text { major decisions. }\end{array}$ \\
\hline Buse \& Twigg (2014) & UK & $\begin{array}{l}\text { to explore the ways that handbag use } \\
\text { can provide insight on the lives of } \\
\text { women living with dementia, and the } \\
\text { role of material objects in the day to day } \\
\text { experiences of people with dementia. }\end{array}$ & $\begin{array}{l}\text { Cross sectional. Ethnographic research in care } \\
\text { homes, and with people with dementia and } \\
\text { their family carers in their own homes. Data } \\
\text { analysed thematically. } \mathrm{N}=23 \text { women with } \\
\text { dementia; } \mathrm{N}=29 \text { family carers; } \mathrm{N}=28 \text { care } \\
\text { home staff }\end{array}$ & $\begin{array}{l}\text { Material objects such as handbags can help retain } \\
\text { connections to identity and facilitate transition into } \\
\text { care. Handbags facilitated telling stories about their } \\
\text { lives, and provided women in care with a sense of } \\
\text { security. The loss of handbags as the dementia } \\
\text { progresses signifies a loss of independence. }\end{array}$ \\
\hline
\end{tabular}


(c) Erol, R., Brooker, D. \& Peel, E. (2016) The impact of dementia on women internationally: An integrative review. Health Care for Women International. doi:10.1080/07399332.2016.1219357

*Please cite published version*

\begin{tabular}{|c|c|c|c|c|}
\hline $\begin{array}{l}\text { Calasanti \& Bowen } \\
\text { (2006) }\end{array}$ & USA & $\begin{array}{l}\text { to explore the extent to which gender } \\
\text { may influence how spouses experience } \\
\text { care work. }\end{array}$ & $\begin{array}{l}\text { Cross sectional. Qualitative, gender-sensitive } \\
\text { constructionist approach, using semi } \\
\text { structured interviews. Analysed thematically. } \\
\mathrm{N}=22 \text { spousal caregivers (13 women, } 9 \text { men), } \\
\text { mean age } 72 \text { yrs (65-83). }\end{array}$ & $\begin{array}{l}\text { Crossing gender boundaries involves assuming gender } \\
\text { inappropriate or atypical tasks - the ease with which } \\
\text { men and women cross these boundaries differs. } \\
\text { Caregivers seek to preserve the sense of self as a } \\
\text { gendered being of the care recipient. }\end{array}$ \\
\hline Carter et al. (2012) & USA & $\begin{array}{l}\text { to address gaps in knowledge and } \\
\text { identify specific sex-based research } \\
\text { questions for future study relating to sex } \\
\text { and gender differences in AD. }\end{array}$ & $\begin{array}{l}\text { Expert opinion, round table discussion with } 14 \\
\text { expert participants: presented data, identified } \\
\text { gaps in knowledge, and discussed future } \\
\text { research questions on sex differences in } A D \\
\text { with a specific focus on women. }\end{array}$ & $\begin{array}{l}\text { over } 70 \% \text { of informal caregivers in the US are women. } \\
\text { Husbands with AD receive } 31 \% \text { more hours of care } \\
\text { than wives do from their husbands. Adult children, } \\
\text { usually daughters, intervene more to help husbands } \\
\text { caring for their wives, particularly as the disease } \\
\text { progresses. Women have lower levels of social support } \\
\text { and poorer psychological and physical health. }\end{array}$ \\
\hline $\begin{array}{l}\text { de la Cuesta- } \\
\text { Benjumea (2011) }\end{array}$ & Spain & $\begin{array}{l}\text { to uncover the strategies that women } \\
\text { caregivers of relatives with advanced } \\
\text { dementia use to rest from care-giving. }\end{array}$ & $\begin{array}{l}\text { Qualitative constructivist grounded theory } \\
\text { approach. Semi-structured interviews with } \\
\mathrm{n}=23 \text { female long term caregivers of relatives } \\
\text { with advanced AD who were completely } \\
\text { dependent. }\end{array}$ & $\begin{array}{l}\text { Women caregivers are the most exposed to } \\
\text { social isolation and to the burden of care. Women } \\
\text { need to disconnect from the caregiver role, and take } \\
\text { leave from caregiving through: Connecting with one's } \\
\text { own life; building moments of life in common with the } \\
\text { sick relative; and keeping in touch with caregiving. }\end{array}$ \\
\hline $\begin{array}{l}\text { Dunham \& Cannon } \\
\text { (2008) }\end{array}$ & USA & $\begin{array}{l}\text { to examine the ways in which caregivers } \\
\text { discuss the issues of power and control, } \\
\text { their use of medical and cultural } \\
\text { knowledge in that process, and the ways } \\
\text { in which that knowledge is resisted. }\end{array}$ & $\begin{array}{l}\text { Cross sectional qualitative interviews with } \\
n=26 \text { female family caregivers in rural and } \\
\text { urban settings. Age range } 29-74 \text {. }\end{array}$ & $\begin{array}{l}\text { Women expressed their responsibility as carers in } \\
\text { gendered terms, as part of their identity as a woman. } \\
\text { There was a recognised lack of fairness that the men } \\
\text { were involved in decision making about care, but not } \\
\text { in the day to day aspects of care. }\end{array}$ \\
\hline Eriksson et al. (2013) & Sweden & $\begin{array}{l}\text { to explore the gendered meaning of } \\
\text { long-term caregiving from the } \\
\text { perspective of women providing home } \\
\text { care for a spouse suffering from } \\
\text { dementia. }\end{array}$ & $\begin{array}{l}\text { Longitudinal qualitative study of } 40 \text { interviews } \\
\text { conducted with } 12 \text { women over } 5 \text { years. }\end{array}$ & $\begin{array}{l}\text { Caregivers reflected on their caregiving activities in } \\
\text { terms of both general and heteronormative } \\
\text { expectations. The act of caring leads to introspections } \\
\text { concerning perceived 'shortcomings' as a caregiver, } \\
\text { and downplaying of the need for support in day-to-day } \\
\text { caring. }\end{array}$ \\
\hline
\end{tabular}


(c) Erol, R., Brooker, D. \& Peel, E. (2016) The impact of dementia on women internationally: An integrative review. Health Care for Women International. doi:10.1080/07399332.2016.1219357

*Please cite published version*

\begin{tabular}{|c|c|c|c|c|}
\hline Flores et al. (2009) & USA & $\begin{array}{l}\text { to provide a clear and in-depth analysis } \\
\text { of how a U.S.-born Latina daughter of } \\
\text { immigrant parents struggles to enact and } \\
\text { honour the value of familism as her } \\
\text { "Hispanic" and U.S. values clash. }\end{array}$ & $\begin{array}{l}\text { Case study of a } 53 \text { year old single US born } \\
\text { Latina female caregiver for her mother who } \\
\text { has dementia using semi-structured } \\
\text { qualitative interviews. }\end{array}$ & $\begin{array}{l}\text { The daughter conforms to the cultural (and familial) } \\
\text { expectation to become her mother's primary } \\
\text { caregiver, albeit with an understanding of the cultural } \\
\text { difference with this and the US approach. Caregiving } \\
\text { remains the responsibility of the family due to both } \\
\text { familistic beliefs and limited access to social services. }\end{array}$ \\
\hline $\begin{array}{l}\text { Godfrey \& El-Badri } \\
\text { (2009) }\end{array}$ & USA & $\begin{array}{l}\text { to discuss the benefits of clinical } \\
\text { strategies for managing dementia in the } \\
\text { ageing woman }\end{array}$ & $\begin{array}{l}\text { expert opinion and review of current practice } \\
\text { and evidence }\end{array}$ & $\begin{array}{l}\text { Clinical and lifestyle factors that affect the onset on AD } \\
\text { include volunteering, mental stimulation such as } \\
\text { reading and playing games, and memory stimulation, } \\
\text { exercise and social engagement. Mental activity, } \\
\text { attaining higher education, and an active lifestyle have } \\
\text { the greatest potential for avoiding or reducing risk of } \\
\text { developing AD or dementia. }\end{array}$ \\
\hline $\begin{array}{l}\text { Godfrey \& Warshaw } \\
\text { (2009) }\end{array}$ & USA & $\begin{array}{l}\text { to shares lessons learned and practical } \\
\text { strategies to address the medical needs } \\
\text { of women whose health may be } \\
\text { compromised as a result of their caring } \\
\text { for others. }\end{array}$ & $\begin{array}{l}\text { expert opinion and review of current practice } \\
\text { and evidence }\end{array}$ & $\begin{array}{l}\text { Anxiety and depression are more common among } \\
\text { women under stress as caregivers. As older women } \\
\text { assume caregiver responsibilities at a more advanced } \\
\text { age, the ability to look after themselves will assume } \\
\text { greater urgency and be harder to achieve. }\end{array}$ \\
\hline Gray et al. (2009) & USA & $\begin{array}{l}\text { to examine ethnic differences in female } \\
\text { dementia family caregivers' knowledge, } \\
\text { attitudes, and beliefs about Alzheimer } \\
\text { disease (AD). }\end{array}$ & $\begin{array}{l}\text { Cross sectional quantitative structured } \\
\text { interviews with } 236 \text { female caregivers caring } \\
\text { for a relative with } A D . N=84 \text { Anglo, } n=83 \\
\text { Hispanic/Latino and } n=48 \text { Chinese American } \\
\text { women. Measures used: Knowledge of } A D \\
\text { and Epidemiology/Aetiology Disease Scale; } \\
\text { perception of AD treatment effectiveness; } \\
\text { perceived threat of AD; AD information } \\
\text { source. }\end{array}$ & $\begin{array}{l}\text { Differences were found in knowledge and attitudes } \\
\text { and information sources between ethnic groups. } \\
\text { Socially and culturally based constructions of dementia } \\
\text { can impact all aspects of caregiving, including } \\
\text { understanding and interpreting symptoms, help } \\
\text { seeking behaviours, patient and family's treatment } \\
\text { preferences and expectations, and compliance with } \\
\text { treatment. }\end{array}$ \\
\hline
\end{tabular}


(c) Erol, R., Brooker, D. \& Peel, E. (2016) The impact of dementia on women internationally: An integrative review. Health Care for Women International. doi:10.1080/07399332.2016.1219357

*Please cite published version*

\begin{tabular}{|l|l|l|} 
Neufeld et al. (2007) & Canada & $\begin{array}{l}\text { to understand non-supportive } \\
\text { interactions within the context of } \\
\text { relationships and social settings. }\end{array}$ \\
\hline Price (2011) & UK & $\begin{array}{l}\text { to explore the care-giving experiences } \\
\text { lesbian women whose care-giving } \\
\text { relationships occurred within a range of } \\
\text { familial and social contexts. }\end{array}$ \\
\hline $\begin{array}{l}\text { Romero-Moreno et } \\
\text { al (2014) }\end{array}$ & Spain & $\begin{array}{l}\text { to analyse the moderator role of feelings } \\
\text { of guilt on the relationship between } \\
\text { frequency of leisure activities and } \\
\text { depressive symptoms in dementia family } \\
\text { caregivers, in particular daughter } \\
\text { caregivers }\end{array}$ \\
\hline
\end{tabular}

Longitudinal, part of a wider qualitative study on women as caregivers. One or two in-depth interviews were conducted over three phases with $n=15$ women caring for a family member with dementia

Qualitative study with $n=8$ lesbian participants caring for a parent with dementia. Age range 23-62 yrs. Analysed thematically.

\section{Quantitative study with $\mathrm{n}=351$ family}

caregivers recruited via Social and Health care centres. $78.6 \%$ female, $21.4 \%$ male; mean age 60.19; most were daughters (59\%), wives $(20 \%)$, husbands (11\%) and sons (11\%).

Measures: Caregiver guilt questionnaire, revised memory and behaviour problems checklist, Barthel Index (functional status) leisure time satisfaction assessment, CES-D scale (depression).
Women caregivers identified non-supportive interactions from family/friends and health providers: negative (blaming, criticising, refusing requests for support); ineffective (intended to be helpful but not giving the support needed, inappropriate advice) and absent (need for support was not recognised, intimidation, being in conflict with others).

Particular issues face those not living in

heteronormative family contexts, such as lesbian carers of family and friends. Importance of reliance on support from wider networks of friends outside the biological family, especially where family relationships have been strained prior to the diagnosis. Need to incorporate the contributions of families of choice into assessment and care provision processes, procedures and practices.

There is a gender difference in how guilt is

experienced, and also within different kinship sub groups. 
(c) Erol, R., Brooker, D. \& Peel, E. (2016) The impact of dementia on women internationally: An integrative review. Health Care for Women International. doi:10.1080/07399332.2016.1219357

*Please cite published version*

\begin{tabular}{|c|c|c|c|c|}
\hline $\begin{array}{l}\text { Simpson \& Carter } \\
\text { (2013) }\end{array}$ & USA & $\begin{array}{l}\text { to obtain a better understanding of the } \\
\text { role of mastery (global and caregiving) in } \\
\text { wives' versus daughters' experience of } \\
\text { caring for a person with dementia. }\end{array}$ & $\begin{array}{l}\text { Cross sectional quantitative study of } n=33 \\
\text { wives (mean age } 70.7 \text { ) and } 34 \text { daughters } \\
\text { (mean age 54.7) caring for persons with } \\
\text { dementia were enrolled. Measures: Global } \\
\text { mastery scale; caregiving mastery scale; } \\
\text { Perceived stress scale; CES-D scale, dementia } \\
\text { severity rating scale; Neuropsychiatric } \\
\text { Inventory. }\end{array}$ & $\begin{array}{l}\text { Daughters reported more days with poorer mental } \\
\text { health compared with wives; both reported similar } \\
\text { levels of stress and depressive symptoms. The } \\
\text { correlations between stressors, caregiver stress, and } \\
\text { depressive symptoms were significant for wives but } \\
\text { not daughters. Caregiver mastery was strongly related } \\
\text { to stress and depressive symptoms for wives but not } \\
\text { for daughters. }\end{array}$ \\
\hline Toepfer et al. (2014) & Germany & $\begin{array}{l}\text { to examine the meaning system and } \\
\text { interpretative frame that caring } \\
\text { daughters and wives draw upon to } \\
\text { reconstruct filial and spousal identities in } \\
\text { the adjustment process of role-making } \\
\text { and meaning-making. }\end{array}$ & $\begin{array}{l}\text { Cross sectional semi-structured interviews } \\
\text { with } n=29 \text { female caregivers } 16 \text { wives (mean } \\
\text { age } 67.5 \text { ) and } 13 \text { daughters (mean age 51.6). }\end{array}$ & $\begin{array}{l}\text { Highlight the dementia caregivers' dilemma between } \\
\text { aspiration and reality of perceiving themselves as good } \\
\text { carers and explains why dementia caregivers do not } \\
\text { use support services. }\end{array}$ \\
\hline $\begin{array}{l}\text { Ward-Griffin et al. } \\
(2006)\end{array}$ & Canada & $\begin{array}{l}\text { to report on the mothers' accounts of } \\
\text { receiving care from their daughters, } \\
\text { thereby bringing elderly women } \\
\text { from the margin to the centre of the } \\
\text { debate on dementia care. }\end{array}$ & $\begin{array}{l}\text { Longitudinal qualitative study guided by } \\
\text { feminist and life course perspectives; two } \\
\text { interviews conducted } 6-9 \text { months apart; } \\
\text { separate interviews were conducted with the } \\
\text { mother and daughter. } N=10 \text { mothers with } \\
\text { dementia (mean age } 88 \text {; range } 75-98 \text {; MMSE } \\
\text { score >=17) and } N=15 \text { caregiver daughters } \\
\text { (mean age } 49.6 \mathrm{yrs} \text { ) }\end{array}$ & $\begin{array}{l}\text { All mothers received some degree of help, such as } \\
\text { personal care, transportation, housekeeping, or meal } \\
\text { preparation, from their daughters. All described } \\
\text { gratitude for care received, but guilt for being a } \\
\text { burden. Demonstrates a need to listen to views of } \\
\text { women with dementia }\end{array}$ \\
\hline $\begin{array}{l}\text { Ward-Griffin et al. } \\
(2007)\end{array}$ & Canada & $\begin{array}{l}\text { to guide and advance nursing knowledge } \\
\text { of mother-daughter relationships in the } \\
\text { dementia care process. }\end{array}$ & $\begin{array}{l}\text { Longitudinal qualitative study guided by } \\
\text { feminist and life course perspectives; two } \\
\text { interviews conducted } 6-9 \text { months apart; } \\
\text { separate interviews were conducted with the } \\
\text { mother and daughter. } \mathrm{N}=10 \text { mothers with } \\
\text { dementia (mean age } 88 \text {; range } 75-98 \text {; MMSE } \\
\text { score >=17) and } \mathrm{N}=15 \text { caregiver daughters } \\
\text { (mean age } 49.6 \mathrm{yrs} \text { ) }\end{array}$ & $\begin{array}{l}\text { Four types of mother-daughter relationships within } \\
\text { the dementia care process were: custodial, } \\
\text { cooperative, combative, and cohesive. Custodial and } \\
\text { cooperative were more task focused, combative and } \\
\text { cohesive were more emotion focused. Contextual } \\
\text { factors, such as expectations of care and levels of } \\
\text { support, influenced these relationships. }\end{array}$ \\
\hline
\end{tabular}


(c) Erol, R., Brooker, D. \& Peel, E. (2016) The impact of dementia on women internationally: An integrative review. Health Care for Women International. doi:10.1080/07399332.2016.1219357

*Please cite published version*

\begin{tabular}{|l|l|l|} 
Westwood (2014) & UK & $\begin{array}{l}\text { to address the gap in knowledge about } \\
\text { how the respective sexualities and sexual } \\
\text { identities of lesbian and bisexual women } \\
\text { inform their experiences of dementia, } \\
\text { how they are supported in dementia } \\
\text { care provision. }\end{array}$ \\
\hline Shriver et al. (2010) & USA & $\begin{array}{l}\text { to provide an overview of how AD affects } \\
\text { women in the USA }\end{array}$ \\
\end{tabular}

information from 4 sources: systematic review of ageing, gender and sexuality, focused on dementia; semi-structured interviews with 36 lesbians and bisexual women; Dementia Services Equality Impact Assessment; professional experience of the author. Data was synthesised and clustered into themes. anthology of case studies, essays and experiences relating to women and dementia in America
Lesbian and bisexual women with dementia are differently affected in relation to residential dementia provision in terms of: less recognition; increased need for concealment; reduced opportunities for identity and memory work; and a lack of choice in provision.

65 per cent of the 5.3 million people living with

Alzheimer's are women, and 10 million American women either have Alzheimer's or are caring for someone with the disease. Alzheimer's effects are felt across society. 
(C) Erol, R., Brooker, D. \& Peel, E. (2016) The impact of dementia on women internationally: An integrative review. Health Care for Women International. doi:10.1080/07399332.2016.1219357

\section{Women living with dementia}

The main themes emerging from the literature were about identity, and maintaining independence around decision-making. Relatively few papers that focused on the experiences of women with dementia actually included the views and perceptions of women themselves (Borley et al. 2014; Buse \& Twigg, 2014; Ward-Griffin et al., 2006; Ward-Griffin et al., 2007).

\section{Identity}

The identity of women living with dementia needs to be considered as part of a whole family system, which includes their wider role prior to the onset of dementia, and to examine how this impacts on the changing dynamics of family interactions after diagnosis (Borley et al., 2014). The transition from "carer" to "cared-for" can be especially challenging, and reinforcing women's identity as a central figure in the family was a key factor in maintaining quality of life (Borley et al., 2014). Material objects and possessions can offer continuity with past social identities, as well as providing a sense of comfort and security. For example, a study of women with dementia and handbags found that the bags enabled connections to memories and identities and that keeping bags symbolised resistance to loss of identity (Buse \& Twigg, 2014). Heterosexual spousal carers also supported their partner with dementia to retain their identity, through maintaining a level of gendered sense of self and appearance, such as applying make-up for a female partner (Calasanti \& Bowen, 2006). For lesbian and bisexual women, having their identity recognised and acknowledged can be problematic within heteronormative care contexts, which may 
(C) Erol, R., Brooker, D. \& Peel, E. (2016) The impact of dementia on women internationally: An integrative review. Health Care for Women International. doi:10.1080/07399332.2016.1219357

*Please cite published version*

lead to avoidance of support services (Price, 2010; Price, 2011; Westwood, 2014). In some countries, identity maintenance is difficult due to lack of understanding of dementia generally (Mushi et al., 2014; Spittel, 2014). For example, in Ghana, older women's cognitive impairment or disorientation was reported to result in social exclusion and relocation to 'witch camps' (Alzheimer's and Related Disorders Association Ghana, 2012).

\section{Maintaining Independence}

There are difficulties in adapting to changing relationships and needs as dementia progresses (Ward-Griffin et al., 2007), and relinquishing traditional gender roles within the family (Borley et al., 2014). Recognising the need for help, and accepting support was difficult when maintaining independence was still important to the person with dementia. Mothers with dementia described their gratitude for daughters taking care of them, but at the same time reported feeling that they were a burden to them, introducing the concept of 'grateful guilt' (Ward-Griffin et al., 2006). Mothers needing care from their daughters wanted to keep some degree of control and independence over the caregiving relationship (Watt et al., 2014), and maintain their dignity (Ward-Griffin et al., 2006; Dunham \& Cannon, 2008).

\section{Women family caregivers}

The majority of papers reviewed focused on the experience of women family caregivers. The themes emerging from these studies were roles and identities; cultural expectations and motivation for providing care; impact of caregiving and coping strategies. 
(C) Erol, R., Brooker, D. \& Peel, E. (2016) The impact of dementia on women internationally: An integrative review. Health Care for Women International. doi:10.1080/07399332.2016.1219357

\section{Roles and identities}

Dementia significantly impacts not only on the person diagnosed, but also their family and friends (Peel, 2017). The decline in cognitive function experienced by people with dementia means increasing levels of care, often provided by women, usually wives, daughters, or daughters-in-law (World Health Organisation and Alzheimer's Disease International, 2012; Gray et al., 2009; Wezel et al., 2016; Ono et al., 2010). Most partners or adult children providing long-term support for someone living with dementia will experience relational and role change (Dunham \& Cannon, 2008; Boylestein \& Hayes, 2012; Toepfer et al., 2014) whereby they will eventually see themselves as a carer or caregiver - and these dynamics are often experienced differently for women and men (Carter et al., 2012; Boylestein \& Hayes, 2012; Baker \& Robertson, 2008; Friedmann \& Buckwalter, 2014; Eriksson et al., 2013; Hayes et al., 2010; Russell, 2007; Calasanti \& King, 2007; Dunkle et al., 2014). While husbands appeared to find it more challenging to adapt to taking on new daily household tasks, such as taking on the role of being the food provider (Russell, 2007; Boyle, 2013; Fjellström et al., 2010), adding to their stress as a caregiver, they were more likely to ask for help to perform these tasks (Sun et al., 2008), and have more informal help (Brown et al., 2007; Forbes et al., 2008). Women were reported to be more prepared to take on additional gendered tasks, and it was often viewed as a gradual extension of their existing work within their household (Calasanti \& Bowen, 2006).

\section{Cultural expectations}


(C) Erol, R., Brooker, D. \& Peel, E. (2016) The impact of dementia on women internationally: An integrative review. Health Care for Women International. doi:10.1080/07399332.2016.1219357

*Please cite published version*

Views about traditional gendered cultural and societal expectations of the caregiver role assume women have a 'natural aptitude for caring' (Toepfer et al., 2014), and the desire to enhance the wellbeing of their family members (Ducharme et al., 2011), with differences between men and women caregivers highlighted in a number of studies (Papastavrou et al., 2007; Gibbons et al., 2014). A higher proportion of women (39\%) than men (33\%) report they had no choice in becoming an informal caregiver (Alzheimer's Association, 2014). Reasons for becoming a caregiver included feeling a complex mix of expectation and obligation, along with love, and gratitude for the person with dementia, repaying the care they received as children (Flores et al, 2009; Price, 2011; Ward-Griffin et al., 2006; Dunham \& Cannon, 2008; Toribio-Díaz, 2013). Religious reasons were also cited in more recent papers for voluntarily providing care (Watt et al., 2014; Wezel et al., 2016;

Friedmann \& Buckwalter, 2014). There is a legal responsibility on families to provide elder care in Sri Lanka and other Asian countries (Watt et al., 2014; SEARO, 2012) within multigenerational households. Family care is seen in some cultural contexts to be superior to professional care as it is more loving and secure (Flores et al, 2009; Gray et al., 2009; Wezel et al., 2016).

\section{Impact of caregiving}

While there are positive factors associated with becoming a caregiver, namely pride and satisfaction (Watt et al., 2014), providing care to a person with dementia is a long-term commitment with a potential negative health impact on the caregiver. Women provide care for a longer period of time than men (Shriver \& Alzheimer's Association, 2010) and spend more hours per day undertaking caregiving tasks 
(C) Erol, R., Brooker, D. \& Peel, E. (2016) The impact of dementia on women internationally: An integrative review. Health Care for Women International. doi:10.1080/07399332.2016.1219357

*Please cite published version*

(Kim et al., 2011). There appears to be a consensus that female caregivers experience higher levels of burden, stress and depressive symptoms than male caregivers, with similar outcomes being reported across different countries and settings (Iavarone et al., 2014; Papastavrou et al., 2009; Davies et al., 2012; Akpınar et al., 2011; Prince et al., 2012; Takano \& Arai, 2005; Stewart et al., 2014; Zhang et al., 2006; Pöysti et al., 2012; Välimäki et al., 2009), although there are some conflicting reports on this (Croog et al. 2006). This is independent of their relationship to the care recipient and their characteristics, and care structures in place (Prince et al., 2012; Peel \& Harding, 2014). However, the type and quality of the relationship between the caregiver and the care recipient, along with their sense of obligation to provide care influence the outcomes of caregiving on women's health (Ward-Griffin et al., 2007; Hodgins et al., 2011). Daughters acting as the primary caregiver reported higher burden and depression levels than sons providing care (Papastavrou et al, 2009). Daughters providing care were more likely to have additional caring responsibilities for children, and hold down employment, leading to a conflict between multiple and competing roles (Egset \& Myklebust, 2011; Simpson \& Carter, 2013). The extent and nature of wider family interaction and support for women providing care also influenced their experience as caregivers (Neufeld et al., 2007), with frustration at negative attitudes towards their caregiving activities, or ineffective offers of help that did not match what was needed, or no support when it was expected. The financial impact of dementia was also apparent, from the costs of obtaining health and social care (World Health Organisation and Alzheimer's Disease International, 2012), and also from a reduction or loss of income. One fifth of women caregivers reduced their working 
(C) Erol, R., Brooker, D. \& Peel, E. (2016) The impact of dementia on women internationally: An integrative review. Health Care for Women International. doi:10.1080/07399332.2016.1219357

*Please cite published version*

hours to part time (Alzheimer's Association, 2014). As well as the immediate impact of the loss of income, reducing the level of employment limits the caregivers personal development and the opportunity to gain support from and build social networks through work (Toribio-Diaz et al., 2013).

\section{Coping Strategies}

Both quantitative and qualitative studies suggest that men and women adopt different coping strategies within their caregiving role (Calasanti \& Bowen, 2006; Egset \& Myklebust, 2011; Etters et al., 2008; Papstavrou et al., 2007; Iavarone et al., 2014; Pretorius et al., 2009). Men focus on problem solving and accomplishing tasks, preferring to make sense of their experiences at a cognitive level, whereas women focus more on the quality of task performance and emotional support, albeit with some cross over between these approaches (Calasanti \& Bowen, 2006; Egset \& Myklebust, 2011; Etters et al., 2008; Pretorius et al., 2009). Women caregivers following more emotion-focused coping strategies had more negative responses to the stress of the caregiving situation (Iavarone et al., 2014; Papstavrou et al., 2007; Etters et al. 2008; Hong \& Coogle, 2016) leading to higher levels of distress. Emotion-focused strategies are influenced by gender, and strongly related to burden, trait anxiety and, to a lesser extent, dementia severity (Iavarone et al., 2014). Women's greater levels of distress are thought to be related to the cultural expectations for women to provide care, whereas men receive greater community recognition and endorsement for taking on that role (Iavarone et al., 2014). Given the differences in the coping strategies adopted, and the effects of these on health, caregivers, especially women, may benefit from specific health education 
(C) Erol, R., Brooker, D. \& Peel, E. (2016) The impact of dementia on women internationally: An integrative review. Health Care for Women International. doi:10.1080/07399332.2016.1219357

*Please cite published version*

programmes that focus on understanding the behaviour of relatives with dementia and how to cope with their own feelings about this (Papstavrou et al., 2007).

Few studies focused on the physical health and health promotion of caregivers, with the focus instead being on self-care behaviours (Hodgins et al., 2011). Targeted health promotion may benefit female caregivers, who take part in fewer health promoting activities than men (Gibbons et al., 2014). For instance, one Spanish study showed that, although overall physical health of female caregivers caring for a person with dementia was similar to non-caregivers, the caregiver group smoked more and were more likely to classify themselves as being physically inactive (Gusi et al., 2009). There are differences between kinship groups; daughter caregivers were more likely to have experienced recent weight gain, and develop high blood pressure than spousal caregivers (Rabinowitz \& Gallagher-Thompson, 2007). In the US, white caregivers were significantly more likely to smoke and have a heart condition than Latina caregivers, although Latina caregivers were less likely to rate their health as very good or excellent (Rabinowitz \& Gallagher-Thompson, 2007). Targeting specific interventions designed for particular kinship or ethnic groups, may help address specific patterns of health behaviours and conditions needed to improve health outcomes, and maintain caregiver health in order to provide adequate care (Gusi et al., 2009; Rabinowitz \& Gallagher-Thompson, 2007, Godfrey \& El-Badri, 2009; Godfrey \& Warshaw, 2009).

\section{Support for caregivers}


(C) Erol, R., Brooker, D. \& Peel, E. (2016) The impact of dementia on women internationally: An integrative review. Health Care for Women International. doi:10.1080/07399332.2016.1219357

*Please cite published version*

Support is needed to enable informal caregivers to continue in this role in the longer-term. The Alzheimer Disease International Reports (Prince et al, 2012), which collect data from LMICs, point to the fact that the use of paid carers in LMICs was generally associated with lower carer strain for the main family caregiver (Prince et al., 2012). As well as supporting the person with dementia, access to respite care, ranging from a few hours in-home help, attending a day-centre, or temporary residential care enables the caregiver to maintain their identity outside that of the caregiver role, and engage in other activities (World Health Organisation and Alzheimer's Disease International, 2012). As women caregivers are the most exposed to social isolation and the burden of care, they may benefit most from respite from caring, in maintaining their identity in relation to others (de la CuestaBenjumea, 2011; Romero-Moreno et al., 2014). As with other forms of formal services, the availability and cost of respite care differs widely in different areas and there may be cultural reasons for not welcoming respite care services in some countries. A WHO survey found that 5 out of 8 (62.5\%) high-income countries provided respite services, whilst only 3 out of 22 (13.6\%) LMICs did, although in a further three LMICs, respite was provided through a private provider or local Alzheimer organization (World Health Organisation and Alzheimer's Disease International, 2012).

\section{Discussion}

Our integrative review focusing on women with dementia and women caregivers highlights a number of issues. Whilst this review provides an overview of the research about women and dementia from across the world, there are limitations, 
(C) Erol, R., Brooker, D. \& Peel, E. (2016) The impact of dementia on women internationally: An integrative review. Health Care for Women International. doi:10.1080/07399332.2016.1219357

*Please cite published version*

with findings based on only recently published English language papers potentially missing locally published research.

In the literature reviewed, the perspective of women living with dementia was largely absent, and the majority of the researchers focused on women as family caregivers. The review highlighted methodological variations and conflicting outcomes between studies of the impact of caregiving on physical and emotional health and wellbeing, making it difficult to present an accurate picture of the true impact of dementia on women. Few studies reporting quantitative measures of burden and health impact present data about changes in levels of burden, depression and anxiety before the dementia diagnosis compared to after a diagnosis. Most studies used a cross sectional design, with few presenting longitudinal data about changes over time. Where longitudinal data were available, the follow up periods were relatively short in relation to the length of the typical dementia journey. Further longitudinal research into the impact of dementia on women as caregivers is needed, in order to understand the impact of caring throughout the dementia trajectory, with a greater focus on cohort studies to compare women in different settings over time.

Despite some ambiguity in some of the data, the overwhelming outcome from the research is that across all regions and settings, women bear the brunt of the incidence of dementia and the responsibility for caring within the family. There is a consensus across the research evidence that caring for a person with dementia is stressful, with implications for the health, emotional and financial wellbeing of 
(C) Erol, R., Brooker, D. \& Peel, E. (2016) The impact of dementia on women internationally: An integrative review. Health Care for Women International. doi:10.1080/07399332.2016.1219357

*Please cite published version*

caregivers. Much of the evidence points to how men and women adapt to changes in their roles and identities, realigning their expectations within the relationship, and needing to take on different tasks. The gender differences need to be understood by public health policymakers, and health and social care professionals working with the caregivers. Despite many intervention studies having all or mostly female participants, few discussed the issue of gender within their findings.

Much of the research published to date has focused on a reliance on family care for people with dementia. As family structures are changing, particularly with migration from rural to urban areas in LMICs, the number of people living alone or with a partner rather than in extended family structure is increasing (Chen et al., 2014). Very little research emerged on women with dementia without family caregivers, or the impact of migration of younger family members on care provision for the older family members remaining behind. Researchers and policymakers also need to take account of those not living in heteronormative family contexts; lesbian, gay, bisexual and trans people with dementia, who may have 'families of choice' rather than relationships recognized legally or socially (Westwood, 2014). Further research is also needed with caregivers, such as friends or unmarried partners, who do not fit the categories that are predominantly covered in the current research.

Many studies recommended avoiding a one-size-fits-all approach to understanding caregiving, reinforcing the need to provide approaches to care and interventions designed for specific groups and circumstances (Hellström et al., 2014). National dementia strategies need to take account of gender issues. The term 'women 
(C) Erol, R., Brooker, D. \& Peel, E. (2016) The impact of dementia on women internationally: An integrative review. Health Care for Women International. doi:10.1080/07399332.2016.1219357

*Please cite published version*

caregivers' does not refer to a homogeneous group; instead it encompasses a

diverse mix of people in different roles and with a wide variety of characteristics:

wives, daughters, daughters-in-law, working, retired, lesbian, mothers with young children, single, married etc. These factors, along with cultural, religious, financial and other socio-demographics factors, and their own personal perspectives, make it difficult to generalize about the requirements of the caregiver, and highlight the importance of assessing individual needs. The needs of women with dementia and women caring for a person with dementia are extensive and varied, and need to be acknowledged and supported. There are a number of ways this needs to be addressed. At a national level, the impact of dementia on women needs to be fully understood and acknowledged; health policies need to be established to ensure that the health and social care workforce is skilled and knowledgeable about dementia and about the types of intervention that can support all women affected by dementia.

\section{Acknowledgements}

Thanks Mike Splaine of Splaine Consulting and colleagues at Alzheimer's Disease International for their invaluable support. This research was supported by Red \& Yellow Care and WomenAgainstAlzheimer's. The authors' work is independent of the funders.

\section{References}

(References of studies included in the integrative review are identified with an asterisk)

AAARP (2015). National Caregiving Survey of Registered Voters aged 40 and older. Retrieved from: www.aaarp.org/research 
(C) Erol, R., Brooker, D. \& Peel, E. (2016) The impact of dementia on women internationally: An integrative review. Health Care for Women International. doi:10.1080/07399332.2016.1219357

*Please cite published version*

*Akpınar, B., Küçükgüçlü, Ö., \& Yener, G. (2011). Effects of gender on burden among caregivers of Alzheimer's patients. Journal of Nursing Scholarship, 43(3), 248-254.

Alzheimer's and Related Disorders Association Ghana (2012). They Are NOT Witches. Retrieved from: http://alzheimersgh.org/care-for-them/\#more-'

*Alzheimer's Association (2014). 2014 Alzheimer's Association Report. Alzheimer's Disease Facts and Figures. Alzheimers and Dementia, 10(2) e47-e92.

Alzheimer's Disease International (2009). World Alzheimer Report 2009. London: Alzheimer's Disease International.

Alzheimer's Disease International (2010). World Alzheimer Report 2010; The Global Economic Impact of Dementia. London: Alzheimer's Disease International.

Alzheimer's Disease International (2013). The global impact of dementia 2013-2050. London: Alzheimer's Disease International.

Alzheimer's Disease International (2015). The Global Impact of Dementia. An analysis of prevalence, incidence, cost and trends. London: Alzheimer's Disease International.

Alzheimer's Society (2011). Support. Stay. Save. London: Alzheimer's Society.

*Baker, K. L., \& Robertson, N. (2008). Coping with caring for someone with dementia: Reviewing the literature about men. Aging and Mental Health, 12(4), 413-422.

Bamford, S. (2011). Women and Dementia - Not forgotten. London: The International Longevity Centre - UK. 
(C) Erol, R., Brooker, D. \& Peel, E. (2016) The impact of dementia on women internationally: An integrative review. Health Care for Women International. doi:10.1080/07399332.2016.1219357

*Please cite published version*

*Borley, G., Sixsmith, J., \& Church, S. (2014). How does a woman with Alzheimer's disease make sense of becoming cared for? Dementia: The International Journal of Social Research and Practice, doi: 10.1177/1471301214561647

*Boyle, G. (2013). Facilitating decision-making by people with dementia: is spousal support gendered? Journal of Social Welfare \& Family Law, 35(2), 227-243.

*Boylstein, C., \& Hayes, J. (2012). Reconstructing Marital Closeness While Caring for a Spouse with Alzheimer's. Journal of Family Issues, 33(5), 584-612.

Braun, J. (2012). Dementia: A woman's global health issue. Washington: Alzheimer's Disease International.

*Brown, J. W., Chen, S. L., Mitchell, C., \& Province, A. (2007). Help-seeking by older husbands caring for wives with dementia. Journal of Advanced Nursing, 59(4), $352-360$.

Bruckner, T. A., Scheffler, R. M., Shen, G., Yoon, J., Chisholm, D., Morris, J., Fulton, B., Dal Poz, M., \& Saxena, S. (2011). The mental health workforce gap in low- and middle-income countries: a needs-based approach. Bulletin of the World Health Organization, 89(3), 184-194.

*Buse, C., \& Twigg, J. (2014). Women with dementia and their handbags: Negotiating identity, privacy and 'home' through material culture. Journal of Aging Studies, 30, $14-22$

*Calasanti, T., \& Bowen, M. E. (2006). Spousal caregiving and crossing gender boundaries: Maintaining gendered identities. Journal of Aging Studies, 20(3), 253263. 
(C) Erol, R., Brooker, D. \& Peel, E. (2016) The impact of dementia on women internationally: An integrative review. Health Care for Women International. doi:10.1080/07399332.2016.1219357

*Please cite published version*

*Calasanti, T., \& King, N. (2007). Taking 'women's work' 'like a man': Husbands' experiences of care work. The Gerontologist, 47(4), 516-527.

*Carter, C.L., Resnick, E.M., Mallampalli, M., \& Kalbarczyk, A. (2012). Sex and Gender Differences in Alzheimer's Disease: Recommendations for Future Research. Journal of Women's Health, 21(10), 1018-1023.

Chen, S., Boyle, L. L., Conwell, Y., Xiao, S., \& Chiu, H. F. K. (2014). The challenges of dementia care in rural China. International Psychogeriatrics, 26(07), 1059-1064.

Coogle, C. L., Parham, I. A., \& Young, K. A. (2007). Job satisfaction and career commitment among nursing assistants providing Alzheimer's care. American Journal of Alzheimer's Disease and Other Dementias, 22(4), 251-260.

*Croog, S. H., Burleson, J. A., Sudilovsky, A., \& Baume, R. M. (2006). Spouse caregivers of Alzheimer patients: problem responses to caregiver burden. Aging and Mental Health, 10(2), 87-100.

Cummings, G., Spiwek T., Hewko, S., Cooper, S., Lynch, S. \& Huynh, H. (2013). Shining A Light On The Unregulated Healthcare Aide Workforce. Final Report. Edmonton: ClearOutcomes and University of Alberta. Retrieved from: http://www.trec.ualberta.ca/

*Davies, H. D., Sridhar, S. B., Newkirk, L. A., Beaudreau, S. A., \& O’Hara, R. (2012). Gender differences in sexual behaviors of AD patients and their relationship to spousal caregiver well-being. Aging and Mental Health, 16(1), 89-101.

*de la Cuesta-Benjumea, C. (2011). Strategies for the relief of burden in advanced dementia care-giving. Journal of Advanced Nursing, 67(8), 1790-9. 
(C) Erol, R., Brooker, D. \& Peel, E. (2016) The impact of dementia on women internationally: An integrative review. Health Care for Women International. doi:10.1080/07399332.2016.1219357

*Please cite published version*

*Ducharme, F., Lévesque, L., Lachance, L., Kergoat, M., \& Coulombe, R. (2011).

Challenges associated with transition to caregiver role following diagnostic disclosure of Alzheimer disease: A descriptive study. International Journal of Nursing Studies, 48(9), 1109-1119.

*Dunham, C. \& Cannon, J. (2008). "They're still in control enough to be in control": Paradox of power in dementia caregiving. Journal of Aging Studies, 22(1), 45-53.

*Dunkle, R. E., Feld, S., Lehning, A. J., Kim, H., Shen, H. W., \& Kim, M. H. (2014). Does Becoming an ADL Spousal Caregiver Increase the Caregiver's Depressive Symptoms? Research on Aging, 36(6), 655-682.

*Egset, A. S., \& Myklebust, J. O. (2011). Dementia in the family: Two Norwegian case studies. Dementia: The International Journal of Social Research and Practice, 10(4), 571-585.

Elliott, K.-E. J., Scott, J. L., Stirling, C., Martin, A. J., \& Robinson, A. (2012). Building capacity and resilience in the dementia care workforce: a systematic review of interventions targeting worker and organizational outcomes. International Psychogeriatrics, 24(6), 882-894.

Elliott, K.-E. J., Stirling, C. M., Martin, A. J., Robinson, A. L., \& Scott, J. L. (2013). Perspectives of the community-based dementia care workforce: "Occupational communion" a key finding from the Work 4 Dementia Project. International Psychogeriatrics, 25(5), 765-774.

*Eriksson, H., Sandberg, J., \& Hellström, I. (2013). Experiences of long-term home care as an informal caregiver to a spouse: Gendered meanings in everyday life for female carers. International Journal of Older People Nursing, 8(2), 159-165. 
(C) Erol, R., Brooker, D. \& Peel, E. (2016) The impact of dementia on women internationally: An integrative review. Health Care for Women International. doi:10.1080/07399332.2016.1219357

*Please cite published version*

*Etters, L., Goodall, D., \& Harrison, B. E. (2008) Caregiver burden among dementia patient caregivers: A review of the literature. Journal of the American Academy of Nurse Practitioners, 20(8), 423-428.

Evercare (2009) The Evercare® Survey of The Economic Downturn and its Impact on Family Caregiving. Bethesda, MD: National Alliance for Caregiving. Retrieved from:

http://www.caregiving.org/pdf/research/EVC_Caregivers_Economy_Report\%20 FINAL_4-28-09.pdf .

*Fjellström, C., Starkenberg, Å., Wesslén, A., Licentiate, M.S., Bäckström, A., \& FaxénIrving, G. (2010). To be a good food provider: An exploratory study among spouses of persons with Alzheimer's disease. American Journal of Alzheimer's Disease and Other Dementias, 25(6), 521-526.

*Flores, Y. G., Hinton, L., Barker, J. C., Franz, C. E., \& Velasquez, A. (2009). Beyond Familism: A Case Study of the Ethics of Care of a Latina Caregiver of an Elderly Parent With Dementia. Health Care for Women International, 30(12), 1055-1072.

*Forbes, D. A., Jansen, S. L., Markle-Reid, M., Hawranik, P., Morgan, D., Henderson, S., ... \& Kingston, D. (2008). Gender differences in use and availability of home and community-based services for people with dementia. Canadian Journal of Nursing Research, 40(1), 38-59.

*Friedemann, M. \& Buckwalter, K. (2014). Family Caregiver Role and Burden Related to Gender and Family Relationships. Journal of Family Nursing, 20(3), 313-336. 
(C) Erol, R., Brooker, D. \& Peel, E. (2016) The impact of dementia on women internationally: An integrative review. Health Care for Women International. doi:10.1080/07399332.2016.1219357

*Please cite published version*

*Gibbons, C., Creese, J., Tran, M., Brazil, K., Chambers, L., Weaver, B., \& Bédard, M. (2014). The psychological and health consequences of caring for a spouse with dementia: A critical comparison of husbands and wives. Journal of Women \& Aging, 26(1), 3-21.

*Godfrey, J. R., \& El-Badri, N. S. (2009). Toward optimal health: advising aging women about dementia. Journal of Women's Health, 18(7), 929-933.

*Godfrey, J. R., \& Warshaw, G. A. (2009). Toward optimal health: considering the enhanced healthcare needs of women caregivers. Journal of Women's Health, 18(11), 1739-1742.

*Gray, H.L., Jimenez, D.E., Cucciare, M.A., Tong, H.Q., \& Gallagher-Thompson, D. (2009). Ethnic differences in beliefs regarding Alzheimer disease among dementia family caregivers. American Journal of Geriatric Psychiatry, 17(11), 92533.

*Gusi, N., Prieto, J., Madruga, M., García, J. M., \& Gonzalez-Guerrero, J. L. (2009). Health-related quality of life and fitness of the caregiver of patient with dementia. Medicine and Science in Sports and Exercise, 41(6), 1182-1187.

Harden, A., \& Thomas, J. (2005). Methodological issues in combining diverse study types in systematic reviews. International Journal of Social Research Methodology, 8, 257-271.

*Hayes, J., Zimmerman, M. K., \& Boylstein, C. (2010). Responding to symptoms of Alzheimer's disease: Husbands, wives, and the gendered dynamics of recognition and disclosure. Qualitative Health Research, 20(8), 1101-1115. 
(C) Erol, R., Brooker, D. \& Peel, E. (2016) The impact of dementia on women internationally: An integrative review. Health Care for Women International. doi:10.1080/07399332.2016.1219357

*Please cite published version*

Hellström I., Eriksson H. \& Sandberg J. (2014). Chores and sense of self: Gendered understandings of voices of older married women with dementia. International Journal of Older People Nursing, 10, 127-135.

*Hodgins, M. J., Wuest, J. \& Malcolm, J. (2011). Modeling the effects of past relationship and obligation on changes in the health and health promotion of women caregivers of family members with dementia. Research in Nursing \& Health, 34(6), 440-56.

${ }^{*}$ Hong, S. C., \& Coogle, C. L. (2016). Spousal Caregiving for Partners With Dementia A Deductive Literature Review Testing Calasanti's Gendered View of Care Work. Journal of Applied Gerontology, 35(7), 759-787.

*Iavarone, A., Ziello, A. R., Pastore, F., Fasanaro, A. M., \& Poderico, C. (2014).

Caregiver burden and coping strategies in caregivers of patients with Alzheimer's disease. Neuropsychiatric Disease and Treatment, 10, 1407.

Jackson, N., \& Waters, E. (2005). Criteria for the systematic review of health promotion and public health interventions. Health Promotion International, 20(4), 367-374.

*Kim, H., Chang, M., Rose, K., \& Kim, S. (2011). Predictors of caregiver burden in caregivers of individuals with dementia. Journal of Advanced Nursing, 68(4), 846855.

Lantz, M. S. (2009). Psychiatry rounds. Who cares for the caregiver? Clinical Geriatrics, 17(10), 6-8. 
(C) Erol, R., Brooker, D. \& Peel, E. (2016) The impact of dementia on women internationally: An integrative review. Health Care for Women International. doi:10.1080/07399332.2016.1219357

*Please cite published version*

*Mushi, D., Rongai, A., Paddick, S.-M., Dotchin, C., Mtuya, C., \& Walker, R. (2014).

Social representation and practices related to dementia in Hai District of

Tanzania. BMC Public Health, 14(1), 260. doi:10.1186/1471-2458-14-260

*Neufeld, A., Harrison, M. J., Hughes, K., \& Stewart, M. (2007). Non-supportive interactions in the experience of women family caregivers. Health and Social Care in the Community, 15(6), 530-541.

Ochayi, B., \& Thacher, T. D. (2006). Risk factors for dementia in central Nigeria. Aging and Mental Health, 10(6), 616-620.

*Ono, T., Tamai, A., Takeuchi, D., \& Tamai, Y. (2010). Predictors of outcomes from a ward for demented elderly: gender differences. Psychogeriatrics, 10(1), 21-28.

*Papastavrou, E., Kalokerinou, A., Papacostas, S. S., Tsangari, H., \& Sourtzi, P. (2007). Caring for a relative with dementia: family caregiver burden. Journal of Advanced Nursing, 58(5), 446-457.

*Papastavrou, E., Tsangari, H., Kalokerinou, A., Papacostas, S. S., \& Sourtzi, P. (2009). Gender issues in caring for demented relatives. Health Science Journal, 3(1), 4153.

Peel, E., \& Harding, R. (2014). "It's a huge maze, the system, it's a terrible maze": Dementia carers' constructions of navigating health and social care services. Dementia: The International Journal of Social Research and Practice, 13(5), 642661.

Peel, E. (2017). "It has had quite a lot of reverberations through the family": Reconfiguring relationships through parent with dementia care. In R. Harding, R. 
(C) Erol, R., Brooker, D. \& Peel, E. (2016) The impact of dementia on women internationally: An integrative review. Health Care for Women International. doi:10.1080/07399332.2016.1219357

*Please cite published version*

Fletcher \& C. Beasley (Eds.) Revaluing Care in Theory, Law and Policy: Cycles and connections. (pp. 198-214) London: Routledge.

Pinder, R. (2008). Is Alzheimer's a preventable disease? Annals of General Psychiatry, 7,1 .

*Pöysti, M. M., Laakkonen, M. L., Strandberg, T., Savikko, N., Tilvis, R. S., EloniemiSulkava, U., \& Pitkälä, K. H. (2012). Gender differences in dementia spousal caregiving. International Journal of Alzheimer's Disease, 2012.

*Pretorius, C., Walker, S., \& Heyns, P. M. (2009). Sense of coherence amongst male caregivers in dementia: A South African perspective. Dementia: The International Journal of Social Research and Practice, 8(1), 79-94.

*Price, E. (2010). Coming out to care: gay and lesbian carers' experiences of dementia services. Health \& Social Care in the Community, 18(2), 160-168.

*Price, E. (2011). Caring for mum and dad: Lesbian women negotiating family and navigating care. British Journal of Social Work, 41(7), 1288-1303.

Prince, M. (2004). Care arrangements for people with dementia in developing countries. International Journal of Geriatric Psychiatry, 19(2), 170-7.

*Prince, M., Brodaty, H., Uwakwe, R., Acosta, D., Ferri, C. P., Guerra, M., Huang, Y., Jacob, K. S., Llibre Rodriguez, J., Aquiles, S., Sosa, A. L., Williams, J. D., Jotheeswaran, A.T. \& Liu, Z. (2012). Strain and its correlates among carers of people with dementia in low-income and middle-income countries. A 10/66 Dementia Research Group population-based survey. International Journal of Geriatric Psychiatry, 27(7), 670-682. 
(C) Erol, R., Brooker, D. \& Peel, E. (2016) The impact of dementia on women internationally: An integrative review. Health Care for Women International. doi:10.1080/07399332.2016.1219357

*Please cite published version*

*Rabinowitz, Y. G., \& Gallagher-Thompson, D. (2007). Health and health behaviors among female caregivers of elderly relatives with dementia: the role of ethnicity and kinship status. Clinical Gerontologist, 31(2), 1-15.

Robinson, C. A., Bottorff, J. L., Pesut, B., Oliffe, J. L., \& Tomlinson, J. (2014). The Male Face of Caregiving A Scoping Review of Men Caring for a Person With Dementia. American Journal of Men's Health, 8(5), 409-426.

*Romero-Moreno, R., Losada, A., Marquez, M., Laidlaw, K., Fernández-Fernández, V., Nogales-González, C., \& López, J. (2014). Leisure, Gender, and Kinship in Dementia Caregiving: Psychological Vulnerability of Caregiving Daughters With Feelings of Guilt. Journals of Gerontology Series B: Psychological Sciences \& Social Sciences, 69(4), 502-513.

*Russell, R. (2007). Men Doing “Women's Work:” Elderly Men Caregivers and the Gendered Construction of Care Work. Journal of Men's Studies, 15(1), 1-18.

Savitch, N., Abbott, E., \& Parker, G. M. (2015). Dementia: through the eyes of women. Research Report. York: Joseph Rowntree Foundation.

SEARO (2012). Promoting ageing and health - the Sri Lankan experience. Ministries of social services and health. WHO Regional Health Forum, 16(1).

Sherman, C. W., \& Bauer, J. W. (2008). Financial conflicts facing late-life remarried Alzheimer's disease caregivers. Family Relations: An Interdisciplinary Journal of Applied Family Studies, 57(4), 492-503.

*Shriver M. and Alzheimer's Association (2010). The Shriver Report - on Women and Alzheimer's. New York: Free Press. 
(C) Erol, R., Brooker, D. \& Peel, E. (2016) The impact of dementia on women internationally: An integrative review. Health Care for Women International. doi:10.1080/07399332.2016.1219357

*Please cite published version*

*Simpson, C., \& Carter, P. (2013). Mastery A Comparison of Wife and Daughter

Caregivers of a Person With Dementia. Journal of Holistic Nursing, 31(2), 113-120.

Solberg, L. M., Solberg, L. B., \& Peterson, E. N. (2014). Measuring impact of stress in sandwich generation caring for demented parents. GeroPsych: The Journal of Gerontopsychology and Geriatric Psychiatry, 27(4), 171-179.

Spittel, S. (2014). "I am not a witch" Stigmatisation of People with Dementia in Ghana. 29th International Conference of Alzheimer's Disease International. 1-4 May, San Juan.

*Stewart, N., Morgan, D.G., Karunanayake, C.P., Wickenhauser, J.P., Cammer, A., Minish, D., O'Connell, M.E., \& Hayduk, L.A. (2014). Rural Caregivers for a Family Member With Dementia: Models of Burden and Distress Differ for Women and Men. Journal of Applied Gerontology, 26, 1-29.

*Sun, F., Roff, L. L., Klemmack, D., \& Burgio, L. D. (2008). The Influences of Gender and Religiousness on Alzheimer Disease Caregivers Use of Informal Support and Formal Services. Journal of Aging and Health. 20, 937-953

*Takano, M., \& Arai, H. (2005). Gender difference and caregivers' burden in earlyonset Alzheimer's disease. Psychogeriatrics, 5(3), 73-77.

Takeda, M., Tanaka, T., \& Kudo, T. (2011). Gender difference in psychogeriatric disorders. Geriatrics \& Gerontology International, 11(4), 377-382.

*Toepfer, N. F., Foster, J. L., \& Wilz, G. (2014). 'The Good Mother and Her Clinging Child': Patterns of Anchoring in Social Representations of Dementia Caregiving. Journal of Community \& Applied Social Psychology, 24(3), 234-248. 
(C) Erol, R., Brooker, D. \& Peel, E. (2016) The impact of dementia on women internationally: An integrative review. Health Care for Women International. doi:10.1080/07399332.2016.1219357

*Please cite published version*

*Toribio-Díaz, M.E., Medrano-Martínez, V., Moltó-Jordá, JM., \& Beltrán-Blasco, I.

(2013). Characteristics of informal caregivers of patients with dementia in Alicante province. Neurología, 28(2), 95-102.

*Välimäki, T. H., Vehviläinen-Julkunen, K. M., Pietilä, A. M. K., \& Pirttilä, T. A. (2009). Caregiver depression is associated with a low sense of coherence and healthrelated quality of life. Aging and Mental Health, 13(6), 799-807.

*Ward-Griffin, C., Bol, N., \& Oudshoorn, A. (2006). Perspectives of Women with Dementia Receiving Care from Their Adult Daughters. Canadian Journal of Nursing Research, 38(1), 121-146.

*Ward-Griffin, C., Oudshoorn, A., Clark, K. \& Bol, N. (2007). Mother-Adult Daughter Relationships Within Dementia Care. Journal of Family Nursing, 13 (1), p13-32.

*Watt, M.H., Perera, B., Ostbye, T., Ranabahu, S. , Rajapakse H., Maselko, J. (2014). Care-giving expectations and challenges among elders and their adult children in Southern Sri Lanka. Ageing \& Society, 34(5), 838-858.

*Westwood, S. (2014). Dementia, women and sexuality: How the intersection of ageing, gender and sexuality magnify dementia concerns among lesbian and bisexual women. Dementia: The International Journal of Social Research and Practice doi: 1471301214564446.

*Wezel, N. van, Francke, A. L., Devillé, W. L., Blom, M. M., van Grondelle, N. J., \& Kayan-Acun, E. (2016). Family care for immigrants with dementia: The perspectives of female family carers living in the Netherlands. Dementia: The International Journal of Social Research and Practice, 15(1), 69-84. 
(C) Erol, R., Brooker, D. \& Peel, E. (2016) The impact of dementia on women internationally: An integrative review. Health Care for Women International. doi:10.1080/07399332.2016.1219357

*Please cite published version*

Whittemore, R., \& Knafl, K. (2005). The integrative review: updated methodology. Journal of Advanced Nursing, 52(5), 546-553.

World Health Organization and Alzheimer's Disease International (2012) Dementia: A public health priority. Retrieved from http://www.alz.co.uk/WHO-dementiareport

*Zhang, J., Vitaliano, P. P., \& Lin, H.-H. (2006). Relations of Caregiving Stress and Health Depend on the Health Indicators Used and Gender. International Journal of Behavioral Medicine, 13(2), 173-181. 